\title{
KIR2DS3 Gene
}

National Cancer Institute

\section{Source}

National Cancer Institute. KIR2DS3 Gene. NCI Thesaurus. Code C132075.

This gene is involved in the regulation of natural killer cell-dependent immune responses. 